\title{
Green and Lean: a Gemba-Kaizen model for sustainability enhancement
}

\author{
Anass Cherrafi a , Said Elfezazi ${ }^{\mathrm{a}}$, Brion Hurley ${ }^{\mathrm{b}}$, Jose Arturo Garza-Reyes ${ }^{\mathrm{c}}$, Vikas Kumar ${ }^{\mathrm{d}}$, \\ Anthony Anosikec; Luciano Batista ${ }^{\mathrm{e}}$ \\ ${ }^{\text {a }}$ Cadi Ayyad University, Marrakech, Morocco. \\ ${ }^{\mathrm{b}}$ Rockwell Collins, Wilsonville, OR, USA. \\ ${ }^{\mathrm{c}}$ Centre for Supply Chain Improvement, University of Derby, Derby, UK. \\ ${ }^{\mathrm{d}}$ Bristol Business School, University of the West of England, Bristol, UK. \\ ${ }^{\mathrm{e}}$ Northampton Business School, University of Northampton, Northampton, UK
}

\begin{abstract}
Despite the encouraging results obtained from the application of Green Lean, organizations have found the integration of Green and Lean, and their implementation as an integrated approach, challenging, especially when resources are limited. This paper aims to overcome some of these challenges by presenting a model for integrating Lean and Green based on the Gemba-Kaizen approach. The objective is to help organizations reduce their environmental waste in a practical and easy manner with limited resources. The proposed model was developed on the basis of a through literature review on Gemba and Kaizen, conducted on peer-reviewed journal articles and pragmatic books with managerial impact on the subject, and the more than 40 years of accumulated experience of the authors as academics, researchers, industrialists and consultants after having worked on a number of projects for multinational organisations that wanted to implement Lean Six Sigma and/or environmental management systems in various industrial sectors. The model was validated through two cases study in the aerospace and automotive industries. The results showed that the proposed model helped the case organizations to reduce the consumption of resources and improve their environmental performance. The proposed model can be the basis for further research on Lean and Green, contributing to help organizations to improve their sustainability performance. This research presents a first attempt to develop a model which integrates Lean and Green based on a combined Gemba-Kaizen approach.
\end{abstract}

Keywords: Green Lean, Gemba-Kaizen, Environmental Waste.

\section{Introduction}

Manufacturing is a constant game of doing more with less (Hopp and Spearman, 2008). Recently, with the rise of operations, environment, social and quality improvement 
methodologies, such as Lean, Six Sigma, Green, among others, and the increasing concerns for the environment and the social responsibility, the markets dynamic has changed (Cherrafi et al.,2017; Garza-Reyes, 2015a; Digalwar et al., 2013). Traditionally, production efficiency and profitability, and more recently quality, customer satisfaction, and flexibility have been the main concern for organizations (Garza-Reyes, 2015a; Green et al., 2012; Khor, 2012). However, to respond to governmental environmental regulations and the growth of customer demands for services and products that are environmentally sustainable, organizations have been forced to rethink how they manage their processes and operations and to search for innovative ways to do business (Garza-Reyes et al., 2016a; Wong and Wong, 2014; McCarty et al., 2011). According to Bergmiller and McCright (2009), the triple bottom line of sustainability (profit, planet, and people) must be satisfied by organizations to attain a better position in the market. In this scenario, the challenge for organizations is to achieve economic success through strategies that are compatible with and supportive of environmental and social sustainability in order to meet all requirements of the stakeholders (Shah and Ward, 2007). To this end, Lean and Green have emerged as a major parts of the sustainability answer (Cherrafi et al., 2016a; Garza-Reyes, 2015a). As Lean implies the elimination of waste in every area of production, supplier network, design and factory management (Chauhan and Singh, 2012), it is likely to improve resource efficiency and reduce environmental impact (King and Lenox, 2001; Aguado et al., 2013). Green manufacturing is an integrated approach that aims to reduce negative environmental impacts and wastes in every area of product and service life cycle (Thanki, 2016). Green practices allow companies to achieve a set of benefits of long-term performance, especially in terms of cost reduction through a more efficient use of resources (Carvalho et al., 2017).

In this context, the combination of Lean and Green seems natural (Garza-Reyes, 2015a). According to Dües et al. (2013), there is a synergistic relationship between Lean and Green practices, resulting in better economic and environmental performance, especially when the two approaches are integrated by an organization. Research on Lean and Green, as an integrated approach, has been attracting wide interest across the globe in last few years (Cherrafi et al., 2016a). For instance, Pampanelli et al. (2014) proposed a model to integrate Green practices into pure Lean thinking by using a Kaizen approach to reduce production and environmental wastes. Verrier et al. (2016) developed a framework for integrating Lean and Green to improve economic, environmental and social performance. The framework includes Lean and Green intentions indicators and green performance. It requires a panel of companies for benchmarking their projects in order to share best practices and lessons learned. Alves and 
Alves (2015) proposed a model to integrate Lean and sustainability based on cultural transformation to change values, attitudes, outcomes and behaviors. The proposed model provides a detailed description of implementation steps to reduce the consumption of natural resources and eliminate wastes by using Lean techniques and tools. Cherrafi et al. (2016b) explored the synergy between Green and Lean Six Sigma practices by using a detailed framework broken down into five stages and sixteen steps to improve sustainability performance. Their research findings indicate that the integration of Green and Lean can help organizations to reduce resources consumption and minimize their cost of energy and mass streams. Ben Ruben et al. (2017) proposed a Lean Six Sigma framework with environmental considerations to improve operational and environmental performance. The framework is based on DMAIC (define-measure-analyze-improve), where traditional Lean Six Sigma and environmental impact assessment tools are integrated to systematically deploy Lean Six Sigma strategies with environmental considerations.

Despite, this growing body of research on Green Lean, which has tried to enable and/or facilitate the parallel or subsequent implementation of Lean and Green in order to reduce, or eliminate, environmental wastes in manufacturing processes, only a handful of studies have discussed how to integrate the two strategies in a practical and easy manner with limited resources. According to $\mathrm{Ng}$ et al. (2015), the implementation of Green Lean involves important investment and is not viable in situations where there are limited resources. In the context of the financial and economic crisis, most organizations tend to identify a way to develop their operational performance in an environmental friendly way without important changes and large investments.

The aim for this paper is therefore to present a model for integrating Lean and Green based on the Gemba-Kaizen approach. The main variable of this study is to reduce resource consumption in industrial processes.

This paper is organized into seven more sections. In Section 2, a literature review on Lean and Green is presented. In Section 3 a description of the integration of the two strategies is developed, followed by an analysis, in Section 4, of the relationship between Lean and Green's mudas and tools. In Section 5, the model for integrating Lean and Green, and its method of implementation, is presented. Section 6 includes two cases study used as an approach to validate the proposed model. Lastly, in Section 7 the results are discussed and the learned lessons presented, whereas Section 8 includes the conclusions of the research. 


\section{Literature review}

The Lean and Green concepts have achieved high popularity in recent years, even though their contents and meaning are not new. The concept of Lean was initially developed in Japan by Shigeo Shingo and Taiichi Ohno, where it was known as Toyota Production System (Herron and Hicks, 2008). The concept of Lean became popular through Womack and Jones' (1990) book 'The Machine That Changed the World'. We define Lean as a strategy that focuses on the elimination of waste along the value chain (Herron and Hicks, 2008; Dennis, 2007). In the Lean context, waste is defined as "anything other than the minimum amount of equipment, materials, parts, space and time which are absolutely essential to add value to a product" (Russell and Taylor, 2000). Lean identifies seven forms of waste: transport, inventory, motion, waiting, overprocessing, overproduction, and defects. All of these wastes have a direct impact on performance, quality and cost, and these are all non-value-adding operations for which customers do not want to pay (Marriott et al., 2013). To reduce or eliminate these wastes, several techniques and tools that include just-in-time (JIT), total preventive maintenance (TPM), kaizen, 5S, poka-yoke, cellular manufacturing, standardized work, among others, were developed as part of the Lean approach (Herron and Hicks, 2008). The scholar literature has well proven that Lean Manufacturing has a positive impact on operational performance by improving quality and productivity, and reducing lead-times and inventories (Belekoukias et al., 2014; Abdul Wahabet al., 2013; Dal Pont et al., 2008; Shah and Ward, 2007; Hines et al., 2004).

On the other hand, the concept of green manufacturing has emerged as a philosophy to help organizations improve their environmental performance while still achieving their economic objectives (Garza-Reyes, 2015a). Green can be defined as a set of practices that intend to reduce, or limit, the negative environmental impacts of production and improve the efficiency in the use of natural resources (Galeazzo et al., 2013; Moreira et al., 2010). Overall, it intends to eliminate or reduce environmental waste. Environmental waste is defined as "excessive or unnecessary use of substances or resources released to the water, air, or land that could harm human health or the environment" (EPA, 2006). Inspired on the Lean methodology, Hines (2009) defined eight green manufacturing wastes: greenhouse gases, eutrophication, excessive resource usage, excessive power usage, pollution, rubbish, excessive water usage, and poor health and safety. In our study, we use these eight wastes as common negative environmental impacts that organizations should try to reduce/eliminate. These wastes do not only have an impact on the environment but also on the economies of 
organizations and health and safety of their employees (Cherrafi et al., 2016a; Bergmiller and Mccright, 2009; Kleindorfer et al., 2005; Hanson et al., 2004). Minimizing these eights wastes can help organizations to be more sustainable (Verrier et al., 2016).

\section{Integration of Lean and Green}

Globalization of markets and competition has forced many organizations to find an alternative strategy to combine the traditional competitive criteria, i.e. production efficiency, profitability, quality, flexibility, and customer satisfaction with green/sustainable objectives. Green Lean is the result of this combination. The integration of Green and Lean can be seen as a new opportunity for organizations to improve their performance, particularly, environmental and operational (Kitazawa and Sarkis, 2000; Dües et al., 2013). Lean and Green are two compatible strategies because of their joint focus on waste reduction and efficient use of resources. This relationship is evident in the scholarly literature (e.g. Cherrafi et al., 2016a; Bergmiller and Mccright, 2009; Carvalho and Cruz-Machado, 2009; Dües et al., 2013; Franchetti et al., 2009; Hajmohammad et al., 2013; Hanson et al., 2004; Kleindorfer et al., 2005; Larson and Greenwood, 2004). In particular, various studies have discussed and investigated the relationship between Lean and Green by highlighting the divergences and synergies between the two (e.g. Garza-Reyes, 2015a; Bergmiller and Mccright, 2009; Carvalho and Cruz-Machado, 2009), possible benefits of their integration in different contexts (King and Lenox, 2001; Franchetti et al., 2009), their impact on organizational performance and some of their theoretical integration (Hanson et al., 2004; Bergmiller and Mccright, 2009; Kleindorfer et al., 2005; Cherrafi et al., 2016a). In more recent research, Cherrafi et al. (2016a) conducted an extensive literature review on the relationship between Lean and Green. From all this research, it is possible to make the following conclusions:

1. Companies that are Lean can simply integrate Green practices: Lean philosophy has the potential to help organizations to become Green and consequently improve their sustainable performance (Pampanelli et al., 2014; Dües et al., 2012; Hajmohammad et al., 2013; Biggs, 2009; Carvalho and Cruz-Machado, 2009; Mollenkopf et al., 2010). According to Dües et al. (2013), Lean is a catalyst for the deployment of Green practices, which in turn may help to sustain Lean.

2. There is an intrinsic relationship between Lean and Green initiatives, due to their various similarities and synergies (Franchetti et al., 2009; Ng et al., 2015; Dües et al., 2013). Green and Lean initiatives have been considered synergetic because of their 
joint focus on waste reduction, lead time reduction, efficient use of resources, and the use of different techniques and tools to manage people, organizations and their supply chains to satisfy customer needs at the lowest possible cost (Garza-Reyes, 2015a).

3. The integration of Green and Lean strategies benefits firms (EPA, 2009; King and Lenox, 2001; Bergmiller and McCright, 2009; Larson and Greenwood, 2004; Dües et al., 2013; Carvalho and Cruz-Machado, 2009; Hajmohammad et al., 2013). These benefits include cost and lead times reduction, improvement of resources efficiency, increasing of reliability of processes and equipment and improved employee morale and commitment (EPA, 2007; Cherrafi et al. 2016a).

4. The integration of Green and Lean strategies can have a more important, positive impact on bottom-line performance when implemented together rather than separately (Carvalho and Cruz-Machado, 2009; Hanson et al., 2004; Bergmiller and McCright, 2009; Kleindorfer et al., 2005). According to Bergmiller and McCright (2009), Green and Lean strategies can help organizations to reduce cost and waste when practiced individually, with more chance of being successful if they were implemented in parallel. The harmonious combination of these practices leads to achieve an optimal triple bottom line performance (Verrier et al., 2016).

5. Lean techniques and tools are successful when used for reducing environmental and social impacts (Vais et al., 2006; EPA, 2006; EPA, 2003; Franchetti et al., 2009; Chiarini, 2014; Langenwalter, 2006). Many authors have used different Lean techniques and tools to improve environmental performance. Vais et al. (2006) have used Lean tools, such as Kaizen, 5S and autonomous maintenance to reduce natural resources consumption and production outputs in a Romanian secondary tissue paper and board mill. In a recent study conducted by Chiarini (2014) in five European companies, he concluded that VSM can be used to identify the environmental impacts of production processes. $5 \mathrm{~S}$ can be useful for reducing oil leakage and improving waste management. Cellular manufacturing can lead to a decrease in electricity consumption, whereas TPM can help to reduce several environmental impacts of machines, such as oil leakage and emissions of dusts and chemical fumes into the atmosphere (Chiarini, 2014). 


\section{Connection between Lean and Green's mudas and tools}

Through its systematic focus on increasing added value for customers by eliminating different wastes, Lean substantially leads to improve the environmental performance of organizations (King and Lenox, 2001). Reducing common types of Lean waste can contribute to also reduce Green waste, even without directly targeting environmental outcomes (Fliedner, 2008). In an on-line published paper, the US Environmental Protection Agency (EPA) discussed, based on observations in a large sample of American companies, how Lean principles can be used to improve sustainability performance. In this document, the EPA also presented an important table to show the correlation between Lean wastes and their environmental impact. Table 1 show the main effects of each production waste.

Lean offers several techniques/tools to assist organizations in the reduction of wastes. Various authors suggest that these tools also seem to have effects on the reduction of negative environmental impacts, especially in manufacturing companies (Chiarini, 2014; EPA, 2003; EPA, 2009; Franchetti et al., 2009; King and Lenox, 2001b; Langenwalter, 2006; Wilson, 2010). These techniques/tools include 5S, kaizen events, value stream mapping, cellular manufacturing, standard work, visual management, just-in-time, SMED, supplier relationship, poka-yoke, and plant layout reconfiguration. Some of these tools have been adapted and extended in order to achieve more environmental and social progress (Langenwalter, 2006). The use of Lean techniques and tools to improve environmental performance is supported by various reasons. First, the tools already exist, and are well-tested. Second, employees are already familiar with them (Chiarini, 2014; Pojasek, 1999a). Cherrafi et al. (2016b) conducted a review of the scholarly contributions to present the multiple ways in which the techniques and tools of Lean can provide and improve environmental and social benefits. However, the current literature still lacks a precise framework and model for implementing the identified tools and techniques.

According to Lindahl (2005), to integrate techniques and tools into effective and useful method, it is important to take into consideration the users of the method and the context in which it will be used. In general, the method should involve all staff, support collaboration, promote easy learning, be time efficient, and support systematic work procedures (Norell Bergendahl, 1992). Collaboration, cooperation and sharing of information and resources increase mutual understanding of responsibilities and contribute to a learning organization. 
Collaboration has a positive effect on interdepartmental relations and aids performance improvement (Ellinger et al., 2000). In addition, successful continuous improvement demands that mutual trust exists between the people involved in operations and the empowerment of such people to implement improvements (Berglund et al., 2011). Two fundamental principles of Lean that can satisfy these requirements are Kaizen thinking and Gemba walk. According to Imai (1997), the application of the Gemba approach requires Kaizen because Kaizen activities are implemented through the identification and elimination of waste at every moment and for everyone in all workplace processes (Imai, 1997; Imai 1986).

The Gemba walk, linked to Kaizen, can be a powerful tool for associating the Lean and Green paradigms in production processes, through the objective of waste elimination. It allows identifying opportunities for improvement and reducing both Lean and Green wastes.

\section{Model for sustainability improvement based on Gemba-Kaizen}

Due to the focus mostly being placed on radical change and innovation, many organizations fail to effectively improve their sustainability performance, resulting in the eventual degradation of improvements and regressing to previous practices. Using Gemba-Kaizen as a foundation for sustainability can create sustainable results through total enterprise involvement. The basic and most important idea behind the use of the Gemba-Kaizen model is that this initiative involves everyone in an organization working together to make gradual, orderly and incremental improvements without large capital investment. It helps to harness individuals' strengths into a collective effort. In addition, its implementation occurs in deliberate and discrete initiatives. This provides top management with a chance for reflection and correction during implementation processes. Such method helps organizations minimize risk while achieving sustainability.

\subsection{Criteria and approach for the development of the proposed model}

The proposed model was developed using the literature review mentioned in this paper as reference sources. This was done taking into consideration that the model should be systematic, easily understood, simple in structure, and can be implemented without a significant amount of resources by organizations of all sizes and sectors.

The implementation methodology proposed for this model, its respective steps, as well as its keys to manage success were proposed based on the more than 40 years of accumulated experience of the authors as academics, researchers, industrialists and consultants after having embarked on various projects for multinational organisations that wanted to implement Lean 
Six Sigma and/or environmental management systems in a number of industrial sectors. The theoretical and industrial experience of the authors on Green Lean is illustrated through a wide range of reported developments and applications of relevant Green Lean theory and research (e.g. Cherrafi et al., 2017a; Cherrafi et al., 2017b; Garza-Reyes et al., 2016a; GarzaReyes, 2015a; Garza-Reyes, 2015b; Garza-Reyes et al., 2014; etc.).The criteria used and approach followed to develop the proposed model are comparable to those used by Cherrafi et al. (2016b). Figure 1 presents the research methodology used in this study. The proposed model was created, deployed and verified through a process of two stages: intelligence and conception (Moreira et al., 2015). The intelligence stage consisted in analyzing the theory, concepts and models in the area of Green Lean through a literature review. This stage was complemented with the opinions of the authors as according to Rocha-Lona et al. (2013) these play a key role when developing theoretical models which will be implemented in industry. The aim of this phase was to ensure the incorporation of the most relevant and current practical and theoretical knowledge into the proposed model (Garza-Reyes et al., 2016b).

The conception macro-stage included the development, validation and implementation of the proposed model. Similarly to the work of Cherrafi et al. (2016b), discussions with relevant experts and researchers were conducted using written feedback, workshops and conferences. The model was first implemented in a large aerospace manufacturer based in the US in order to verify its validity, overall structure, and make the necessary adjustments before rolling it out to an injection molding company based in Morocco.

\subsection{Structure of the proposed model}

The model proposed is based on the "See, Solve and Sustain" approach (Figure 2). It will work with organizations at any phase of their environmental journey. A cross-functional team is formed to review the current situation (through data collection and hand-on observations) and everyone on the team provides input, and the whole team agrees upon the actual problems occurring. The team discusses problems and issues that are impacting sustainability performance. These issues are captured and brought to the surface for all to see, and matched up with the data. A scientific approach is applied to address the root cause of the problems, and structured techniques and tools of Lean and Six Sigma are used to prevent recurrence of the problems, and identify when new problems arise. The result is involved employees, improved working environment, and efficient processes that take into consideration stakeholders requirements. This will help to develop new processes with less use of resources and environmental waste. It is important to indicate that each phase is conducted according to the Deming's continuous learning and improvement model PDCA (plan-do-check-act). 


\subsection{Operation of the proposed model}

The proposed model integrates the concepts of Gemba-Kaizen and sustainability, supported by a continuous improvement approach. We suggest several simple steps that organizations can take in order to implement the proposed model, and then systematically improve their economic, environmental and social performance. Figure 4 shows the proposed model.

This five step process for conducting a Gemba walk can be applied to any organization's operations having a limited, or poor, environmental performance, for example, to reduce:

- Water consumption

- Toxic air emissions

- Pollution

- Landfill and solid waste

- Hazardous waste

- Energy consumption

The process for a Gemba-Kaizen approach involves a preparation for the Gemba walk, conducting a series of events, gathering and collecting the observations, then conducting kaizen events to evaluate the ideas and determine a rapid implementation plan for the top 3 ideas.

Step 1 - Prepare for the Event

During the Prepare phase, a decision as to which environmental impact an organization would like to reduce should be taken. A meeting is setup with the process owners and management, and past data and costs are gathered for discussion. A business case is established for the environmental impact, and an agreement is made amongst the management team to determine that a Gemba-Kaizen approach is needed. Team members are defined, and a schedule is created. This information can be captured in an event contract or planning worksheet, to capture the ideas and rationale for the event. This information will be shared with the event participants prior and during the event, to explain why their participation is needed. 
Step 2 - Conduct the Event

After getting approval for the event, the Event phase is next. In this phase a plan to execute the Gemba walk is formulated. Depending on the type of environmental impact, multiple Gemba walks may be needed to cover all the areas, and to observe the current situation at different days and times. To this end, we suggest a systematic approach to data collection in order to ensure that the process is stable and reliable, see Figure 3.

Step 3 - Combine and Organize Ideas

After the walk is completed, the team transfers all their observations and ideas onto sticky notes. The participants brainstorm additional ideas, based on the sticky notes. After all ideas have been generated, the participants review the ideas, and begin combining them into similar groups and categorizing them into major themes.

Step 4 - Decide on Improvements

Next, the ideas are ranked by the participants, based on their implementation easiness and how much effect the idea would have on the environmental issue being addressed. The specific savings and costs will not be known at this time, so it will only be an estimate.

After all the ideas are ranked, each participant is given multiple votes, and they can select one or more ideas that they think may have a high impact and are easy to implement. The top 3 ideas with the most votes are selected for further investigation.

Kaizen events are setup for each of the ideas in order to quickly determine if these are feasible and cost-effective. If they are not, then the ideas with the most remaining votes are evaluated next. The outcome of the kaizen events is to identify and quickly implement 3 ideas within 90 days of the Gemba walk.

Step 5- Track and preserve the results

The goal of this step is to measure the results after the implementation of the actions plan. It also aims at ensuring that the implemented improvements are maintained over the time by integrating and managing solutions into the daily work activities. 
Similarly as DMAIC, the proposed model should be considered a problem-solving and improvement process that aims to continuously reduce environmental wastes. Based on this rationale, the "See, Solve and Sustain" approach presented in Figure 2 was proposed to provide a correct and effective way to facilitate the implementation of the proposed model in a structural, systematic, and continuous cycle of improvement manner. It aims also to establish a standardized routine to solve environmental issues by promoting learning and monitoring of the new process conditions.

\subsection{Keys to manage success of the proposed model}

The challenge to implement the proposed model is to recognize how to use Gemba-Kaizen as a systematic methodology and identify the best way to sustain the improvements. Thus, the organization should consider a number of important key elements that are critical to ensure the successful implementation of Gemba-Kaizen projects. As shown in Figure 5, we suggest six keys to ensure the effective implementation of the proposed model:

1. Leadership and people: The commitment and involvement of leadership and people in the implementation efforts is critical for long-term success. Top leaders must develop the mission, vision, goals, strategic direction and promoting an organization culture that takes into consideration internal and external environment in order to improve sustainability performance. In addition, they must be able to ensure communication, motivation and leading of employees to sustain the results and to meet the legal, ethical and societal responsibilities of the organization. Furthermore, the organization should ensure full management's commitment and the involvement of each and every employee to implement the proposed model. Respect for people, empowerment of creativity, learning and recognition play a key role in this context. In turn, people should contribute to the successful implementation of the proposed model according to organization strategies and should work as a team.

2. Lean Six Sigma tools: Lean Six Sigma offer various techniques and tools that can be used by organizations to detect and solve sustainability problems. The tools should be integrated into an organizational culture in order to facilitate the identification and elimination of waste. A rudimentary understanding of Lean Six Sigma tools and their deployment results in ineffectiveness and misapplications. Thus, the application of these tools require training and a co-operative environment.

3. Continuous process improvement: Continuous process improvement is supportive to sustainability and waste reduction. Building an effective culture of process 
improvement is the strategic objective of the proposed model. An organization should create an adequate structure and an appropriate culture for implementing and sustaining a culture of continuous process improvement. The following are critical elements to take into consideration:

- Communication: No organization can over-communicate during a change initiative such as the Gemba-Kaizen initiative, especially during the early phases of deployment. Stakeholders may have misunderstanding about the initiative and their impact on performance. An effective communication with stakeholders at all levels can increase their support and commitment to facilitate the Gemba-Kaizen implementation.

- Training: This is an important element for developing and sustaining processimprovement initiatives such as Gemba-Kaizen. Thus, a training program should be established early to meet the new training needs of the all employees impacted by the change. In addition, a training assessment should be developed to measure the training impacts.

- Measurement: Performance measurement is critical for continuous improvement efforts, it permits organizations to identify process issues, evaluate the effectiveness of an action plan, and monitor progress towards the goals. The model proposed depends on data for its success; performance measurement allows any influencing parameters to be detected and can serve also as a basis for decision-making.

4. Strategic planning: Strategic planning permits an organization to determine objectives and goals, and identify steps that will help it to meet its vision. Strategic planning should support continuous improvement and sustainability, reflect stakeholders imperatives and take into consideration current performance and challenges faced by an organization. Good strategic planning helps decisions about the allocation of necessary human, technical and financial resources for the deployment of the proposed model.

5. Stakeholders: It is crucial for an organization to focus on their stakeholders, because stakeholders can create constraints on a company's business. Stakeholders include customers, employees, investors, regulators, government authorities, local communities and supply-chain partners. The requirements and needs of stakeholders must be continuously identified and verified, the key goal is to determine their main concerns about the projects conducted in order to improve sustainable performance. At this point, an organization must develop a proactive and a durable relationship with 
their stakeholders in a manner that ensures that their projects contribute to the fullest satisfaction of their stakeholders.

6. Results and Knowledge management: The proposed model is not about techniques, tools or methodologies. It is about improving sustainability performance and outcomes in order to achieve better results. In this context, organization should make sure that results are the basis of the initiative. It is important that an organization selects the appropriate indicators to track economic, environmental and social results, because effective feedback of results helps organizations to adjust their actions, practices and plans. In addition, an organization must develop a system for generating and managing knowledge for planning, learning, and decision-making. This knowledge can be generated through numerous ways, including lessons learned from projects, human capital contributions and incorporation of stakeholders' knowledge. This supports the organization to drive continuous improvement and innovation for superior sustainable performance.

\section{Cases study}

This section presents two cases study where the proposed model for integrating Lean and Green based on the Gemba-Kaizen approach has been deployed in two organizations to demonstrate its applicability and test its effectiveness to improve both operational and environmental performance. A case study approach can be considered a valid research methodology, particularly when the study is applicable and suitable for the organization where the research takes place (Woodside, 2010). In recent times, the high volume of published work using the case study research method (e.g. Garza-Reyes et al., 2016a; Villarreal et al., 2016; Garza-Reyes et al. 2016b; Bevilacqua et al., 2015; among many others) indicates its well acceptance in the scholarly literature. Despite this wide acceptance within the academic community as a valid research methodology, the case study approach may still be considered as a limited research method to conclusively validate the effectiveness of the proposed model. However, its replication in other industrial contexts would allow a generalisation and validation of the findings achieved in this research (Yin 2012). Thus, it would fall as part of the future research agenda to test the proposed model through its application in further/different industrial contexts.

It is important to indicate that during these two case studies, we have conducted interviews with cell workers and supervisors. All the interviewed employees had a significant experience of more than 6 years, and were all actively involved in continuous improvement in their sites. To ensure that all answers were reliable and meaningful, we used full-filter questions. A full- 
filter question is a special type of contingency question which first asks if the survey respondents have an opinion, and only if the answer is 'yes', the respondent then provides an opinion.

\section{Case study 1 - Large Aerospace Manufacturer based in the US}

A large aerospace manufacturer was interested in using their knowledge on Lean concepts to reduce electricity usage, the largest utility expense in their budget. A pilot group was identified in the printed circuit board shop, located within the headquarters building, which was the largest electricity user of all buildings within the company. This specific area was selected because there was strong leadership support and Lean knowledge in the area, and because it was possible to separate out their electricity usage cleanly from the rest of the building. This allowed them to understand their actual electricity usage, which did not match the amount they were being charged by Finance in their budget.

\section{Step 1 - Prepare for the Event}

For two weeks prior to the Gemba-Kaizen event, portable electricity meters were hooked up to the substations in the area, to get a baseline of electricity usage, and to have a breakdown of usage by region. This data was analyzed prior to the event, to help the team focus on the largest regions based on usage, and to prioritize where to spend most of their time during the event. The data also helped building support and curiosity from the team to show up and encouraging them to participate in the event, once they understood which areas had the highest usage. An event preparation worksheet was created prior to the event, to make sure leadership was fully supportive of the event, the right people were invited, preparation work was completed, and the event dates and times were correct.

Each team received training prior to the start of the event, the day before the first event day. The training covered the carbon footprint reduction goal of the company, Lean concepts (value added and non-value added uses of electricity), and electricity basics (such as kWh, peak demand, utility rates and carbon footprint calculations). They also reviewed the event preparation worksheet, so the team could understand why their area was selected, why they were selected, and what their role would be in the event.

Step 2 - Conduct the Event 
There were six different observation periods selected for the event:

1. Weekend (Saturday)

2. Startup time (Monday morning)

3. Working time (Monday morning)

4. Breaks (Monday morning)

5. Changeover (Monday afternoon)

6. Shutdown (Monday evening)

Saturday was selected first, as it was a non-working day, when no one was scheduled to be in the area. The objective was to see the workspace when everything should be switch off, and the electricity usage should be the lowest. It was important not to announce to the rest of the employees that an event was taking place, so observations would not be skewed by those not wanting their area to have items left running.

On Saturday, the event teams split up into smaller groups (at least one person from the work area, and the rest from outside the area). Each group took photos and made detailed observations about what they observed that could be a waste of electricity. A template was provided to each team member, to help remind them what and where to look for opportunities. This first session lasted about two hours.

For the startup time, the teams returned early on Monday morning before work began in the area, to see if anything had changed since Saturday. Team members arrived early enough to observe the startup processes as employees came in. They looked to see whether equipment and lights or equipment were turned on right away, or if they were turned on only when needed.

During the working time, they had a chance to interview the employees about observations from the Saturday session and the startup time, and observed how equipment and tools were used during the shift. The team stayed during breaks to see if equipment was switch off or left on while the workers were gone. The team next observed what happened when the shift change took place (whether things were shut off or not). Finally, they observed what happened during shutdown when a shift was completed and people went home for the day (which may look different than when they left for a weekend).

\section{Step 3 - Combine and Organize Ideas}

After all the observations were made, the team meet back together on Tuesday to compare notes and observations in a conference room. Each opportunity to save electricity was written 
on a sticky note, and placed on a whiteboard under the section where the opportunity was observed (e.g. Cafeteria, Press Area, Conference Rooms, Layup Room, Packaging Room, Supplies, Maintenance, Dock, Upstairs, Lab and Plating).

The participants brainstormed additional ideas, based on what they heard and read on the sticky notes from others. After all the ideas had been identified by the team, they reviewed them and began combining similar ones together.

The final list resulted in 20 actions, such as:

- Add automatic timers on ovens;

- Motion sensor on lights;

- Educate employees to turn off personal fans;

- Educate employees to turn of computer monitors;

- Fix leaks in compressed air lines;

- Etc.

\section{Step 4 - Decide on Improvements}

Next, the ideas were ranked by the team members, based on how easy to implement they were (including upfront cost ballpark estimates), and how much impact they thought the idea would have on reducing electricity. The team members use the impact ease matrix to understand which ideas have the biggest impact for the least amount of effort or cost. Then the group votes and rates the project ideas (see Figure 6). A total of six actions were identified as most important with a good chance of being implemented. 


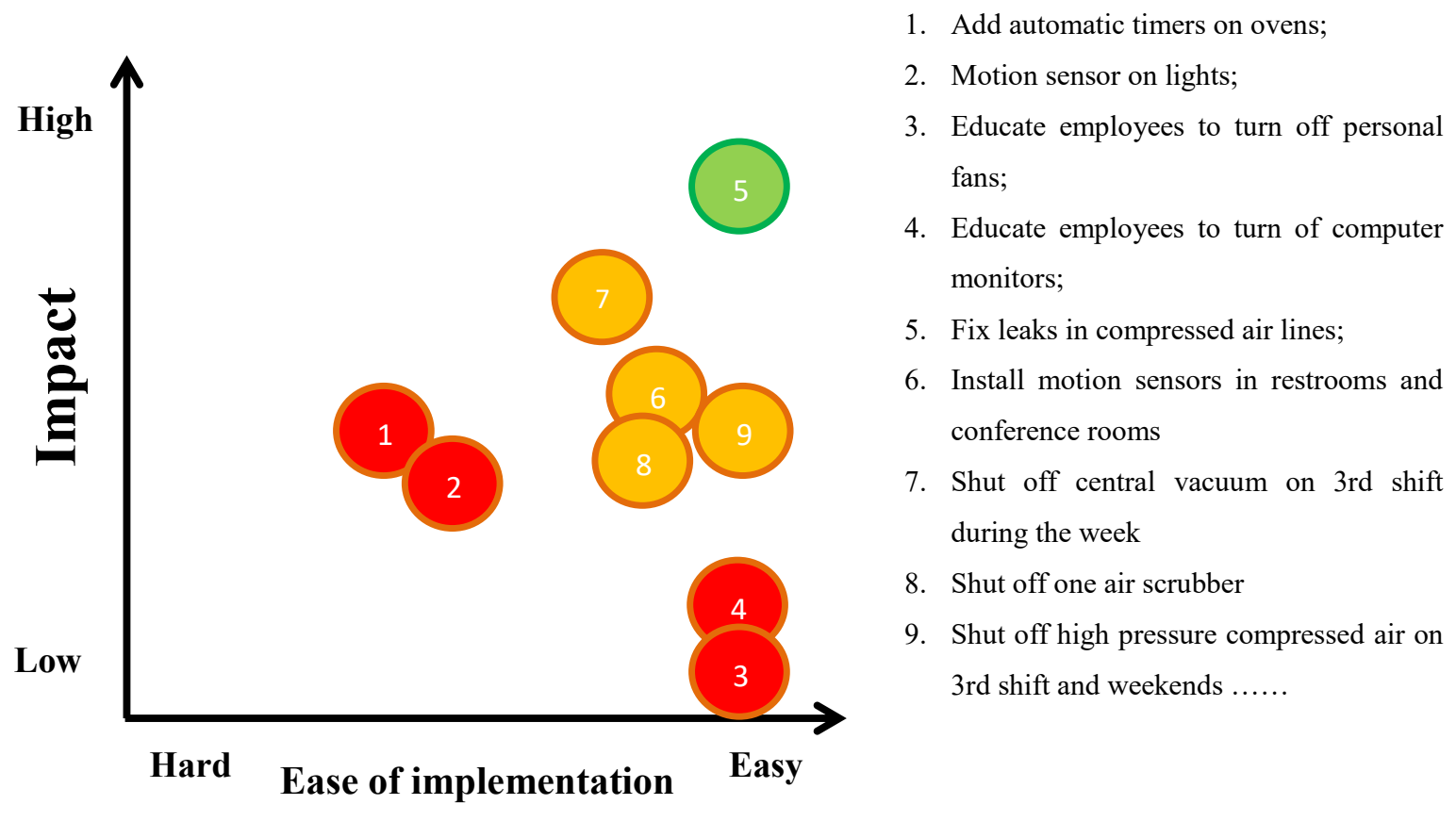

Figure 6. Impact ease matrix.

\section{Step 5- Track and preserve the results}

Exact cost savings were not known right away at the end of the event, so team members signed up to dig into the observations and notes, and perform more detailed analyses and research to get a better estimate of potential cost savings, see Table 2.

After the research and analyses were completed, some of the items had higher upfront costs than expected, or the payback was too long, or the idea was not feasible due to other business factors unknown at the time of the event. The team also looked for actions that could be implemented within 90 days, so some ideas would have taken longer than that, and they were not pursued.

At the end, the team fixed the air leaks within a couple weeks. The estimated cost savings was 5,000 USD, based on the number and size of leaks identified in the event. It is important to note that we can always add more improvement ideas once we get the initial ones completed.

Although this initial event did not save a huge amount of money, the event set the stage for future Gemba-Kaizen events within the company. Over a two-year period, six events were completed in four different facilities within the United States. It was important to test out the approach outside of the headquarter building. This helped expand the knowledge of the electricity reduction efforts to more employees, and verify that the approach could be replicated in smaller buildings with less on-site leadership support. The six events identified 
over $\$ 200,000$ in opportunities, and more than 50 employees were trained on how to see energy waste opportunities.

\section{Case study 2 - Injection Molding Company based in Morocco}

This case study was conducted in a plastic injection molding company specialized in the production of multiple automotive polymeric appearance parts. The company produces around 27 varieties of plastic components and is certified with TS16949 and ISO 14001 standards. The company aimed to improve customer value and its sustainability performance. The company was also interested in reducing the negative environmental impacts of its processes. Top management strongly believed that applying Lean techniques could help the organization to improve both its operational and environmental performances.

\section{Step 1 - Prepare for the Event}

The company was interested in reducing raw material usage and electricity consumption in order to improve its operational and environmental performances. A pilot area was selected based on its resource consumption and strong leadership support and Lean knowledge on this area. A meeting was organized by top management with operators, engineers and senior managers of the area to discuss the need for the project and to instigate enthusiasm and motivation among the participants. A cross-functional team was formed consisting of operators and engineers from the quality, environment and maintenance departments. The project was coordinated by a representative of the top management's team. A planning worksheet was developed to define the fundamental information about the project's specific scope, objectives, participants and schedule (see Figure 7).

\section{Step 2 - Conduct the Event}

The team conducted four observations, within the go-and-see event, in order to take notes and make detailed observations about what could be wasting electricity and raw material using a template with pre-defined items. The team also used that time to interview employees to collect data and find new opportunities to reduce raw material and energy use.

\section{Step 3 - Combine and Organize Ideas}

After the observations, the team conducted a brainstorming session to discuss and analyze the observations about raw material and energy consumption in the injection molding process. The observations were categorized using sticky notes into six categories, namely: Methods, Personnel, Measurement, Environment, Machines and Material. 


\section{Step 4 - Decide on Improvements}

Based on the observations and brainstorming session, some solutions were determined after having been ranked by the participants using voting. Table 3 shows the improvement activities proposed to address the identified wastes.

\section{Step 5 - Track and preserve the results}

After the implementation of the improvement actions, the results showed that raw material and energy consumption had been consistently decreased. The estimated cost savings was 113,000 USD per year.
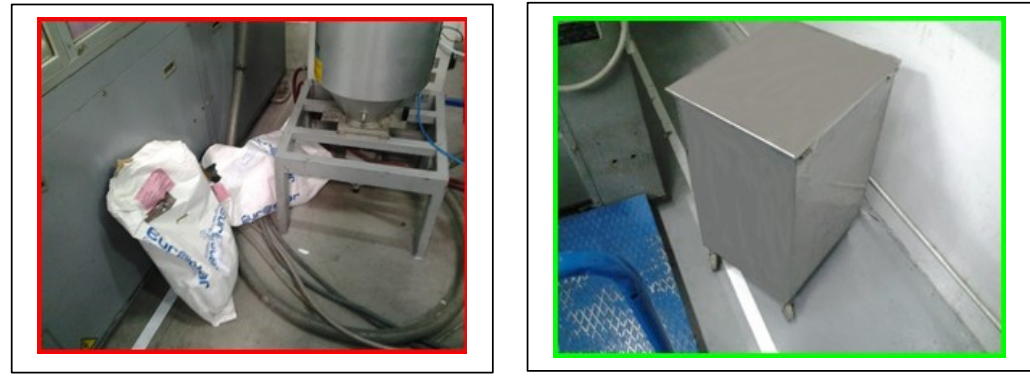

Figure 8. Inappropriate storage of the thermoplastic resin.

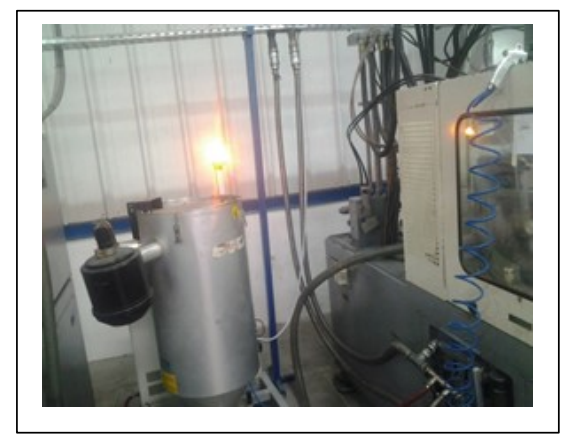

Figure 9. Implementation of poka-yoke: Sensor with alarm.

\section{Discussion}

According to EPA (2007) reducing environmental wastes cannot be targeted by the deployment of Lean only. Even if the Lean approach by its nature can help organizations to achieve environmental results and develop a systemic, continual improvement-based waste elimination culture, Lean methods do not explicitly identify and consider environmental aspects, missing considerable environmental improvement opportunities. Moreover, environmental professionals are rarely involved in Lean projects, frequently conducting efforts to improve environmental performance to operate in a parallel universe to Lean efforts. 
Thus, in this study, we presented a model that integrates the concepts of Gemba-Kaizen and Green, supported by a continuous improvement approach. The proposed model aims to help organizations, especially SMEs to understand the practical implementation of Green Lean through simple steps to simultaneously improve their operational and environmental performance. This study completes our previous contribution conducted between 2013 and 2017 as part of a research project about Green Lean based on industrial projects.

The results have demonstrated that Gemba-Kaizen is an effective and powerful approach to minimize resources consumption. Based on Lean tools and techniques, this approach can help organizations to engage their human resources in identifying opportunities; organize their ideas, and prioritizing those ideas down to the top opportunities to implement. The identified opportunities should be limited in number to minimize the monitoring burden and required resources. The results include also qualitative benefits such as improvement of working conditions and team spirit and cohesiveness. Thus, the results achieved in this study do not only support the logically implicit synergy between Lean and Green and the impact of Gemba-Kaizen on operational and environmental performance, but also that established in the academic literature by authors such as Pampanelli et al. (2014) and Verrier et al. (2016). This suggests that organizations that wish to reduce their environmental impacts can consider the adoption of practices including Gemba walks and Kaizen as a catalyst to achieve this endeavor. Walking through and observing processes as they actually run at a facility can be a simple but effective way to identify waste and find improvement opportunities (EPA, 2007).

In terms of learned lessons, we have identified some that should be taken care of while implementing the proposed model. Firstly, the attitudes and mindsets of employees involved in a Gemba-Kaizen initiative are vital. Poor mindset and misunderstanding of the approach can hinder the deployment process and minimize the expected gains for the company. In addition, a committed top management is crucial for a successful implementation, which must be driven from the top down. Moreover, employee involvement is also important; it can drive Green Lean efforts to achieve great results. Lastly, but most importantly, a mature lean deployment program (i.e., project team members are qualified to work with the different tools such visual management, 5S, causes and effect analysis, brainstorming, affinity diagram and impact ease matrix), in addition to a high level of environmental awareness (i.e., project team members have already been trained in understanding related sustainability concerns and issues).

In the second case study, convincing employee was the most arduous task as many of them were not ready to embark on a Green Lean initiative. It is very natural to encounter resistance 
from employees if one tries to implement new business initiatives. Employees were convinced by citing examples of some Moroccan organizations that have dramatically eliminated and reduced their environmental wastes, improved their working condition and avoiding accidents using the Green Lean approach.

\section{Concluding remarks, limitations and future research directions}

Organizations across the globe are under immense pressure from customers, regulators, and other stakeholders to manage their operations in a responsible manner to improve their environmental performance. Thus, finding a way to improve sustainability performance has been a challenge for many companies that aim to reduce the negative environmental of their industrial processes.

In response to this challenge, this paper proposes a model that integrates the concepts of Gemba-Kaizen and sustainability, supported by a continuous improvement approach. The model utilizes Gemba-Kaizen to ensure the involvement of everyone in an organization to reduce any environmental impact without large capital investment.

The implementation methodology describes a logical sequence of steps. It is systematic, easily understood, and simple in structure and can be implemented without a lot of resources by organizations of all sizes and sectors.

Two case studies were presented with the objective to test the effectiveness of the proposed model. The results demonstrate that organizations can achieve quantitative benefits by integrating and implementing Gemba-Kaizen practices. In addition, these organizations can also benefit from better working conditions and improved team spirit. The results obtained confirm that the model is a suitable strategy for improving environmental performance. Thus, it can be a part of a solution for organizations that are looking to achieve sustainability

In future, the proposed model can be extended to other industrial sectors and manufacturing firms where the need to improve environmental performance is critical. The model can also be modified to extend its scope for reducing other environmental impacts and exploring the integration of more advanced techniques and tools.

\section{Acknowledgement}

The authors would like to thank the industrial managers of the companies who participated in the cases study as well as Dr. S. Azmoun, B. Baadi, E. Elayachi, M. Benzina for their support and enlightenment during this project. 


\section{Reference}

Aguado, S., Alvarez, R., Domingo, R. 2013. "Model of efficient and sustainable improvements in a Lean production system through processes of environmental innovation." Journal of Cleaner Production, 47: 141-148.

Alves, J. R. X., and Alves, J. M. 2015. "Production Management Model Integrating the Principles of Lean Manufacturing and Sustainability Supported by the Cultural Transformation of a Company." International Journal of Production Research. 51 (11), 1-14.

Belekoukias, I., Garza-Reyes, J.A., Kumar, V. 2014. "The impact of lean methods and tools on the operational performance of manufacturing organisations". International Journal of Production Research. 52(18): 5346-5366.

Ben Ruben,R., Vinodh, S., Asokan, P. 2017. "Implementation of Lean Six Sigma framework with environmental considerations in an Indian automotive component manufacturing firm: a case study." Production Planning \& Control. 28(15): 1193-1211.

Berglund, R., Karling, M., Mellby, C. 2011. Det vardefulla engagemanget: En guide for Lean och andra strategier for utveckling, Swerea IVF, Molndal, Sweden in Swedish.

Bergmiller, G.G., McCright, P.R. 2009. "Are Lean and Green programs synergistic?." Industrial Engineering Research Conference, Miami, Florida, USA, May 30-June 3.

Bevilacqua, M., Ciarapica, F.E., Paciarotti, C. 2015. "Implementing Lean Information Management: The Case Study of an Automotive Company." Production Planning \& Control. 26(10): 1-16.

Biggs, C. 2009. Exploration of the integration of Lean and environmental improvement, Thesis, Cranfield University, UK.

Carvalho, H., Govindan, K., Azevedo, S., Cruz-Machado, V. 2017. "Modelling Green And Lean Supply Chain: An Eco-Efficiency Perspective." Resources, Conservation and Recycling. 120:7578.

Carvalho, H., Cruz-Machado, V. 2009. "Lean, agile, resilient and Green supply chain: a review." In Proceedings of the Third International Conference on Management Science and Engineering Management in Bangkok, Thailand, 2009: 3-14.

Chauhan, G., Singh, T.P. 2012. "Measuring parameters of Lean manufacturing realization." Measuring Business Excellence. 16(3): 57-71.

Cherrafi, A., Elfezazi,S., Chiarini, A., Mokhlis,A., Benhida,K. 2016a. "The integration of lean manufacturing, Six Sigma and sustainability: A literature review and future research directions for developing a specific model." Journal of Cleaner Production. 139: 828-846.

Cherrafi, A., El Fezazi, S., Govindan, K., Garza-Reyes, J.A., Mokhlis, A., Benhida, K. 2016b. “A Framework for the Integration of Green and Lean Six Sigma for Superior Sustainability Performance." International Journal of Production Research. DOI: 10.1080/00207543.2016.1266406 (in press).

Cherrafi, A., Elfezazi, S., Chiarini, A., Mokhlis, A., Benhida, K. 2017. "Exploring Critical Success Factors for Implementing Green Lean Six Sigma". International Manufacturing Strategy in a Time of Great Flux. 183-195. 
Chiarini, A. 2014. "Sustainable manufacturing-Greening processes using specific Lean production tools: an empirical observation from European motorcycle component manufacturers." Journal of Cleaner Production. 85: 226-233.

Dal Pont, G., Furlan, A., Vinelli, A. 2008. "Interrelationships among lean bundles and their effects on operational performance”. Operation Management Research. 1: 150-158.

Dennis, P. 2007. Lean production simplified, New York: Productivity Press.

Digalwar, A.K., Tagalpallewar, A.R. and Sunnapwar, V.K. 2013. "Green manufacturing performance measures: an empirical investigation from Indian manufacturing industries." Measuring Business Excellence. 17(4): 59-75.

Dües, C.M., Tan, K.H., Lim, M. 2013. "Green as the new Lean: how to use Lean practices as a catalyst to Greening your supply chain.” Journal of Cleaner Production. 40: 93-100.

Ellinger, A.E., Dougherty, P.J., Keller, S.B. 2000. "The relationship between marketing/ logistics interdepartmental integration and performance in U.S. manufacturing firms: an empirical study." Journal of Business Logistics. 21: 1-22.

EPA. 2006. "The Lean and Environment Toolkit." available at: http://www.epa.gov/lean/environment/toolkits/ index.htm (accessed 10 July 2016).

EPA. 2009. "The Environmental Professional's Guide to Lean \& Six Sigma." available at: www.epa.gov/Lean/ (accessed 10 July 2016).

Fliedner, G. 2008. "Sustainability: a new lean principle." Proceedings of the 39th Annual Meeting of the Decision Sciences Institute, Baltimore, Maryland, USA, 22-25 November.

Franchetti, M., Bedal, K., Ulloa, J., Grodek, S. 2009. "Lean and Green: industrial engineering methods are natural stepping stones to Green engineering." Industrial Engineer. 41(9): 24-29.

Galeazzo, A., Furlan, A., Vinelli, A. 2013. "Lean and green in action: interdependencies and performance of pollution prevention projects." Journal of Cleaner Production. 85: 191-200.

Garza-Reyes, J.A. 2015a. "Green Lean and the need for Six Sigma." International Journal of Lean Six Sigma. 6(3): 226-248.

Garza-Reyes, J.A. 2015b. "Lean and Green - A systematic review of the state of the art literature", Journal of Cleaner Production. 102: 18-29.

Garza-Reyes, J.A., Rocha-Lona, L., Kumar, V. 2015. "A conceptual framework for the implementation of quality management systems." Total Quality Management \& Business Excellence. 26(11-12): 1298-1310.

Garza-Reyes, J.A., Villarreal, B., Kumar, V., Molina Ruiz, P. 2016a. "Lean and Green in the Transport and Logistics Sector - A Case Study of Simultaneous Deployment." Production Planning \& Control. 27(15): 1221-1232.

Garza-Reyes, J.A., Al-Balushi, M., Antony, J., Kumar, V. 2016b. “A Lean Six Sigma framework for the reduction of ship loading commercial time in the Iron Ore Pelletising industry." Production Planning \& Control: 27(13): 1092-1111.

Garza-Reyes, J.A. 2018. "A systematic approach to diagnose the current status of quality management systems and business processes." Business Process Management Journal. DOI: 10.1108/BPMJ12-2016-0248 (in press). 
Green, K.W., Zelbst, P.J., Meacham, J. and Bhadauria, V.S. 2012. "Green supply chain management practices: impact on performance." Supply Chain Management: An International Journal. 17 (3): 290-305.

Hajmohammad, S., Vachon, S., Klassen, R.D., Gavronski, I. 2013. "Lean management and supply management: their role in Green practices and performance." Journal of Cleaner Production. 39: $312-320$.

Hanson, J.D., Melnyk, S.A., Calantone, R.J. 2004. "Core Values and Environmental Management: A Strong Inference Approach.” Greener Management International .40: 29-40.

Herron, C., Hicks, C. 2008. "The transfer of selected lean manufacturing techniques from Japanese automotive manufacturing into general manufacturing (UK) through change agents". Robotics and Computer-Integrated Manufacturing. 24(4): 524-531.

Hines, P. (2009), Lean and Green, The Home of Lean Thinking, 3rd edition ed. Sapartners.

Hopp, W., Spearman, M. 2008. Factory Physics, McGraw-Hill/Irwin, New York.

Imai, M. 1986. Kaizen - The Key to Japan's Competitive Success, Random House, New York, NY.

Imai, M. 1997. Gemba Kaizen, McGraw-Hill, New York, NY.

Khor, M. 2012. Challenges of the Green Economy Concept and Policies in the Context of Sustainable Development, Poverty and Equity: the Context of Sustainable Development and Green Economy, UNEP.

King, A., Lenox, M. 2001. "Lean and Green: an empirical examination of the relationship between Lean production and environmental performance." Production Operation Management.10: $244-256$.

Kitazawa, S., Sarkis, J. 2000. "The relationship between ISO 14001 and continuous source reduction programs." International Journal of Operation and Production Management. 20(2): 225-248.

Kleindorfer, P.R., Singhal, K., van Wassenhove, L.N. 2005. "Sustainable operations management." Production \& Operations Management. 14: 482-92.

Langenwalter, G. 2006. "Life is Our Ultimate Customer: From Lean to Sustainability." Target. 22(1): $5-15$.

Larson, T., Green wood, R. 2004. "Perfect complements: synergies between Lean production and ecosustainability initiatives." Environmental Quality Management.13 (4): 27-36.

Lindahl, M. 2005. Engineering Designers' Requirements on Design for Environment Methods and Tools, Doctoral Diss. Department of Machine Design, Integrated Product Development, KTH Royal Institute of Technology, Stockholm, Sweden.

Marriott, B., Garza-Reyes, J.A., Soriano-Meier, H. and Antony, J. 2013. "An integrated methodology to prioritise improvement initiatives in low volume-high integrity product manufacturing organisations." Journal of Manufacturing Technology Management. 24 (2): 197-217.

McCarty, T., Jordan, M., Probst, D. 2011. Six Sigma for Sustainability - How Organizations Design and Deploy Winning Environmental Programs. New York, NY: McGraw-Hill.

Moreira, F., Alves, A.C., Sousa, R.M. 2010. Towards Eco-efficient Lean Production Systems, Balanced Automation Systems for Future Manufacturing Networks. Springer, Germany.

Ng, R., Low, J.S.C., Song, B. 2015. "Integrating and Implementing Lean and Green Practices based on Proposition of Carbon-Value Efficiency Metric.” Journal of Cleaner Production. 95: 242-255 
Norell Bergendahl, M. 1992. Stodmetoder och samverkan i produktutveckling (Supporting Methods and Collaboration in Product Development), KTH Royal Institute of Technology, Stockholm, Sweden in Swedish.

Pampanelli, A.B., Found, P., Bernardes, A.M. 2014. "A Lean \& Green model for a production cell." Journal of Cleaner Production. 85: 19-35.

Pojasek, R.B. 1999a. "Quality toolbox: Five S's: A tool that prepares an organization for change." Environmental Quality Management. 9(1): 97-103.

Pojasek, R.B. 1999b. "Quality toolbox: Poka-yoke and zero waste." Environmental Quality Management. 9(2): 91-97.

Pojasek, R. B. 1999c. “Quality toolbox: Zeroing.” Environmental Quality Management. 9 (3): 93-97.

Rocha-Lona, L., Garza-Reyes J.A., Kumar, V. (2013), Building quality management systems: selecting the right methods and tools, Productivity Press, CRC Press, Taylor \& Francis, Boca Raton, FL.

Russell, R.S., Taylor, B.W. 2000. Operations Management, Prentice-Hall, Englewood Cliffs.

Shah, R., Ward, P.T. 2007. "Defining and developing measures of Lean production." Journal of Operation Management. 25: 785-805.

Thanki, S. J., Govindan, K., Thakkar, J. 2016. "An Investigation on Lean- Green Implementation Practices in Indian SMEs Using Analytical Hierarchy Process (AHP) Approach.” Journal of Cleaner Production. 135, 284-298.

Vais, A., Viron, V., Pedersen, M., Folke, J. 2006. "Green and Lean at a Romanian secondary tissue paper and board mill — putting theory into practice." Resources, Conservation and Recycling. 46(1): 44-74.

Verrier, B., Rose, B., Caillaud, E. 2016. "Lean and Green strategy: The Lean and Green House and Maturity deployment model." Journal of Cleaner Production. 116: 150-156.

Villarreal, B., Garza-Reyes, J.A., Kumar, V. 2016. "Lean road transportation - a systematic method for the improvement of road transport operations." Production Planning \& Control. 27(1): 865877.

Wilson, A. 2010. Sustainable Manufacturing: Comparing Lean, Six Sigma, and Total Quality Manufacturing, USA: Strategic Sustainability Consulting, Washington, DC.

Womack, J.P., Jones, D.T., Ross, D. 1990. The Machine that Changed the World, Rawson Associates, New York.

Wong, W.P., Wong, K.Y. 2014. "Synergizing an ecosphere of Lean for sustainable operations." Journal of Cleaner Production. 85(15): 51-66.

Woodside, A.G. 2010. Case Study Research: Theory, Methods and Practice. Bingley: Emerald Group Publishing. 